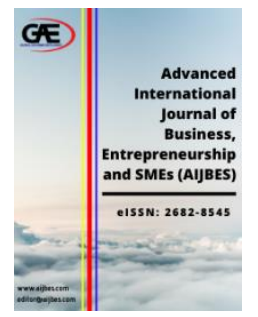

\author{
ADVANCED INTERNATIONAL JOURNAL OF \\ BUSINESS, ENTREPRENEURSHIP AND SMES \\ (AIJBES) \\ www.aijbes.com
}

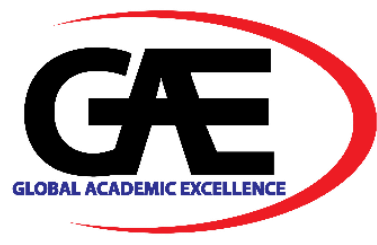

\title{
A STUDY OF CUSTOMER PREFERENCE, CUSTOMER PERCEIVED VALUE, SALES PROMOTION, AND SOCIAL MEDIA MARKETING TOWARDS PURCHASE DECISION OF SLEEPING PRODUCT IN GENERATION Z
}

\author{
Hedwika Avila Diva Putri Kuncoro $^{1 *}$, Nurrani Kusumawati ${ }^{2}$ \\ 1 School of Business and Management, Institut Teknologi Bandung \\ Email: hedwika_avila@sbm-itb.ac.id \\ 2 School of Business and Management, Institut Teknologi Bandung \\ Email: nurrani.k@sbm-itb.ac.id \\ * Corresponding Author
}

\section{Article Info:}

Article history:

Received date: 27.07 .2021

Revised date: 08.08.2021

Accepted date: 27.08 .2021

Published date: 09.09.2021

To cite this document:

Kuncoro, H. A. D. P., \& Kusumawati, N. (2021). A Study Of Customer Preference, Customer Perceived Value, Sales Promotion, And Social Media Marketing Towards Purchase Decision Of Sleeping Product In Generation Z. Advanced International Journal of Business, Entrepreneurship and SMEs, 3 (9), 265-276.

DOI: $10.35631 /$ AIJBES.39018.

\begin{abstract}
:
Sleep is a major factor for human physical and mental health and abnormality in a person's sleep, this can cause sleep disturbances. The emergence of sleep disturbances makes sufferers try various sleep aids that might help sufferers to rest well. In Indonesia, many sleeping products have been created and sold in the market. The large variety of sleeping products with various functions and ways of use is a determining factor in adolescence buying sleeping products. They have several considerations before buying the sleeping products they need and want and it is because nowadays, customers have a lot of choices and considerations when they are choosing products and services. Therefore, it is necessary to understand consumer preferences because they play an important role in making purchasing decisions and in improving the marketing strategy to be implemented. For this research, researchers want to identify the important factors that influence the customers' purchase decision towards sleeping products and find out the product attributes which become preferred by customers. The researcher uses quantitative methods by using questionnaires as primary data and a variety of literature as secondary data. This research uses non-probability sampling and requires a minimum of 200 respondents with criteria aged 17-26 years old and living in Jabodetabek and Bandung. Using Multiple Linear Regression methods, this research aims to identify the relationship between one dependent variable from five independent variables and answer the hypothesis. The overall evidence showed that product, social,
\end{abstract}


Volume 3 Issue 9 (September 2021) PP. 265-276

personal value dimensions, sales promotion, and social media marketing have a significant positive impact on purchase decisions. Therefore, researchers suggest marketers in the sleeping product industry convey product advantages and personal values, use influencers to promote products or make price discounts and use social media to attract customers because these points influence purchasing decisions.

Keywords:

Customer Preference; Purchase Decision; Perceived Value; Sales Promotion; Social Media Marketing

\section{Introduction}

Sleep is a very important human need because sleep is a major factor for human physical and mental health, it has even heightened importance for adolescents (Leger et al., 2012). Sleep is good for energy preservation, nerve recovery and brain plasticity. However, if there is an abnormality in a person's sleep, this can cause sleep disturbances. Sleep disturbances are divided into insomnia, hypersomnolence central disorder, parasomnia, sleep-related movement disorders, and other sleep disturbances. Sleep disorders are common in the late teens (or early adulthood) and have a negative impact on adolescent mental health and function (Kosticova et al., 2018). This can lead to the risk of depression, suicide, and substance use during adolescence (Winsler et al., 2015). It can be said that sleep, physical health, and psychology are related to one another.

Research shows that $50 \%$ of young adolescents have sleep problems and this makes them need to find solutions to their sleep problems (Tu et al., 2019). The emergence of sleep disturbances makes sufferers try various sleep aids that might help sufferers to rest well. Because sleep is the most common health factor and allows many organs to function in a healthy manner, the use of sleeping products tends to reduce long-term health problems. The high number of sufferers of sleep disturbance causes the high sleeping product industry. In 2020, the global market for sleep aids will be $\$ 67.37$ billion. This value is expected to grow at a compound annual growth rate of $6.32 \%$, reaching US \$ 91.53 billion in 2025 . Considering the current situation, in 2020 MarketDataForecast analysts predict that it is expected that the global sleep aid market will grow even more in the future.

There are various ways to reduce sleep disturbance in everyone such as using sleeping pills, consulting, changing lifestyle, meditation, and using daily wear sleeping products. Although daily wear sleeping products are predicted to increase, there are still many people with sleep disturbance who prefer to take medication (sleeping pills) or prescription sleep aid instead of using daily wear sleeping product. In fact, most sleeping pills have side effects ranging from dependence to relieving insomnia and symptoms can come back and even get worse if the sufferer stops taking sleeping pills (Lemmer, 2007). Kripke said on his research that sleeping pills may harm human health or cause death from cancer, heart disease or other diseases. Using non-sleeping pills is considered better because it provides the opportunity to identify, assess and treat many sleep disorders without using drugs, which are often ineffective or exacerbate the problem (Kuhn et al., 1999). Because of this, there are several sleeping products, sleep apps, and natural sleep aids that are safer and can make fall asleep. 
In Indonesia, many sleeping products have been created and sold in the market. There are several local brands that sell sleeping products such as Eucalie, Good Vibes, FOG Apothecary, NYO, Peek Me Goodnight, and others. The large variety of sleeping products with various functions and ways of use is a determining factor in adolescence buying sleeping products. Also, the rise of social media and the technological advances in the sleeping product industry have impacted consumers' relationship to sleep and sleeping products. They view sleep as one of the top factors in their health and well-being, ahead of diet and exercise. Of the many sleeping products available on the market, they have several considerations before buying the sleeping products they need and want. It is because nowadays, customers have a lot of choices and consideration when they are choosing on products and services. Therefore, it is necessary to understand consumer preferences and the product attributes (such as product price, quality, physical form of the product, and others), since they play an important role in making purchasing decisions and in improving the marketing strategy to be implemented. Knowing these customer preferences helps businesses to be accepted by the target market.

\section{Literature Review}

\section{Customer Preferences}

Consumers' preferences for products or brands arise from the combination of many different factors. Some factors come from features of the product itself (e.g., price, durability), while others are attributes of consumers themselves (e.g., goals, attitudes, discretionary income) (Venkatraman et al., 2012). Customers differ greatly in their preferences and may prefer different attributes from the same product, service or market offering (Denizci Guillet and Kucukusta, 2016). It is important to know about customer preference so that businesses can design their offerings to fit the preferences and expectations of customers.

\section{Consumer Perceived Value}

Perceived value defined as customer's perceived preference for an evaluation of those product attributes, attribute performances, and consequences arising from use that facilitate (or block) achieving the customer's goals and purpose in use situations (Aulia et al., 2016). To examine customer perceived value, researchers divide the customer perceived value into three groups of dimension of value which are product-related value, social-related value, and personalrelated value (Aulia et al., 2016). In particular, one study suggested that the influence of these values varied across situations (Nguyen et al., 2015). For example, while functional value appears to be the primary influencer of consumer choice, social value tends to exert a greater influence on decisions involving highly visible products. The results of this study have succeeded in measuring the perceived value of customers from various products such as clothing and durable goods. According to Aulia (2016), customers are expected to be satisfied if these three types of value dimensions are met.

\section{Product-Related Value}


Volume 3 Issue 9 (September 2021) PP. 265-276 DOI 10.35631/AIJBES.39018

Product-related value refers to the customer perspective that product is the source of value which means the product is viewed as benefits rather than as attributes (Aulia et al., 2016). Not only consider product performance or quality, but also customers consider how the product can be used easily without difficulty or confusion when using it when evaluating product functions. Huber et al. (2001) argues that customers face risks associated with uncertainty or negative consequences when consuming products and that is part of the functional value.

\section{Social-Related Value}

Social-related value refers to the customer perspective that society is the source of value which means the customers view society as the place where they can obtain some benefits through the interaction with other people. These benefits can be seen from two basic needs perspectives, the need for acceptance and the need for compliments (Aulia et al., 2016). As explained by Maslow (1943) acceptance in society is part of a basic need (deficit need) where the failure of the product to meet this need will cause feelings of discomfort that lead to unfavourable attitudes and behaviour towards certain products.

\section{Personal-Related Value}

Personal-related value is closely related to the self-concept possessed by customers (Aulia et al., 2016). The self-concept in personal-related value is how they value themselves as a person. Sweeney and Soutar (2001) state that values include enjoyment, relaxation, feelings of pleasure, and pleasure and call them emotional or personal values.

\section{Sales Promotion}

Sales promotion plays a vital role in marketing in any business nowadays. Sales promotion consists of techniques aimed at increasing sales for a short period of time (Familmaleki et al., 2015). Sales promotions are usually short-term activities designed by manufacturers to influence individuals to buy a product. Sales promotion as the communication of information in two parties, sellers and potential buyers, obtained to influence customer decisions (Dawood Shamout, 2016). Sales promotion can be broadly divided into two types: consumer sales promotions and trade sales promotion. In case of consumer sales promotion, the incentive is given directly to customers to motivate them to purchase the product (Dubey, 2014). It is a pull strategy as it motivates customers to approach selling points to buy the promoted product. Researches show that a large percentage of company sales are being made based on sales promotions (Yashodha, n.d.).

\section{Social Media Marketing}

Social media has become the tool to express belief, ideas and manner in a absolute new way (Xuegeng, 2012). The rapid growth of social media and social networking sites has provided new avenues for marketers to contact customer (Yogesh and Yesha, 2014). Social media marketing is a hot topic for companies that allows companies to establish a communication channel with its customers, market their products, build brand equity, and boost clientele faithfulness (Xuegeng, 2012). When consumers want to buy a product, they tend to search for the information on the website. However, more than $80 \%$ of customers leave the website without finding what they are looking for. So, people tend to ask for advice from the people they trust the most (friends or family) from social media (Khatib, 2016) as well as social media 
Volume 3 Issue 9 (September 2021) PP. 265-276

DOI 10.35631/AIJBES.39018

is slowly replacing traditionally done product reviews. It becomes a key business component of social media which allows consumers to evaluate products, make or get recommendations from contacts or friends, and link current purchases to future purchases through status updates (Yogesh and Yesha, 2014). In addition, the use of social media presents a valuable tool for companies where satisfied product users can recommend the product to other potential users.

\section{Purchase Decision}

There are five steps in the customer purchase decision process. The first step is need recognition or problem recognition, second is information search, third step is comparison of alternatives, fourth is final purchase and the fifth step is post-purchase behavior (Prasad et al., 2019). The consumer decision-making process can be described as the phases that consumers go through in making a final purchase decision (Hanaysha, 2018). Purchase decision involves an order of choices formed by the consumer before buying a product which starts once the customer has a willingness to fulfil a need (Hanaysha, 2018). Also, this research reported that marketing managers should understand customers' consumption process and the benefits of organizational products or service in their perceptions to understand consumers' purchasing decisions. The role of marketers in this phase arises when using advertising, personal selling, and packaging to generate recognition for the products or services they offer. The purchase decision is influenced by various factors such as social, cultural, demographic, personal, economic etc (Jothi, 2015). Eventually, consumers evaluate alternatives and choose from the brand that best suits them and satisfies their needs.

\section{Generation Z}

The generation born between 1995 and 2010 is referred to as Generation Z or Gen Z (Daeid, 2008). Compared to Millennials, Gen $Z$ is more connected in learning and communication styles. Gen $Z$ is more aware of health problems than previous generations (Mat Zain et al., 2021). To approach Generation $Z$, businesses need to know who they are, what they want and how they want. Research shows that Generation $\mathrm{Z}$ is a consumptive buyer who tends to spend money right away if he has a desire for a particular product. Generation $\mathrm{Z}$ has special reasons for shopping, especially online shopping, namely convenience, perceived lower prices, variety of products and time efficiency (Simangunsong, 2018).

Adolescence is marked by dramatic changes in sleep (Colrain and Baker, 2011). Older adolescents go to bed later, have an increased preference for evening activities, and sleep less than younger adolescents. This behaviour change is driven by external factors, notably increased pressures from social activities and by biological circadian factors (Colrain and Baker, 2011). A number of studies have consistently reported that adolescents do not get enough sleep and that their sleep patterns are characterized by staying up late (Liu, 2004). This is related to sleep time, and sleepiness, and the composition of the sleep EEG. In fact, they experience daytime sleepiness, and this starts to happen as puberty approaches (Dahl and Lewin, 2002). This high level of sleepiness causes sleep disorders such as narcolepsy or sleep apnea. Also, social stresses including fear, anxiety, and emotional arousal are thought to interfere with sleep in adolescents. The consequence of delayed sleep phase is that adolescents find it difficult to fall asleep and wake up that creates a cycle of symptoms like lack of sleep or jet lag. 
The following hypothesis proposed for this study is as follows:

$\mathrm{H} 1$ = Product-Related Value have positive impact on consumer purchase decision.

$\mathrm{H} 2$ = Social-Related Value have positive impact on consumer purchase decision.

H3 = Personal-Related Value have positive impact on consumer purchase decision.

$\mathrm{H} 4=$ Sales promotion have positive impact on consumer purchase decision.

H5 = Social media marketing have positive impact on consumer purchase decision .

\section{Methodology}

Researcher set Purchase Decision towards Sleeping Product as topic for this research that represents Indonesian local brands and products. Then, researcher identified the problems within the topic and done a preliminary study about customer preferences toward sleeping product and do literature review to gain an understanding of the topic and frame research questions. After setting the research framework based on the most suitable variables, questionnaire was made to get real responses to answer the research objectives. The questionnaire's title is "Customer Preferences on Sleeping Product", conducted in Bahasa Indonesia to minimize the misunderstanding by the respondents. The first part is the introduction, the second part is to collect the respondents' data, the third until the seventh part are based on the previous research regarding the customer preference, customer perceived value, social media marketing, sales promotion, and purchase decision. Each of the questions were labelled as shown in table 1.

Table 1. Research Variables

\begin{tabular}{|l|l|l|}
\hline \multicolumn{1}{|c|}{ Part } & Labels & \multicolumn{1}{|c|}{ Questions / Statements } \\
\hline \multirow{4}{*}{$\begin{array}{l}\text { Part I - Purchase } \\
\text { Decision }\end{array}$} & PD1 & $\begin{array}{l}\text { I feel good about my decision to purchase a product from } \\
\text { this brand }\end{array}$ \\
\cline { 2 - 3 } & PD2 & I will positively recommend this brand to other people \\
\cline { 2 - 3 } & PD3 & I frequently purchase from this brand \\
\cline { 2 - 3 } & PD5 & I intend to purchase again from this brand in the future \\
\hline \multirow{4}{*}{$\begin{array}{l}\text { Part II - Product- } \\
\text { Related Value }\end{array}$} & FF3 & $\begin{array}{l}\text { The sleeping product should have acceptable standard of } \\
\text { safety }\end{array}$ \\
\cline { 2 - 3 } & FF1 & The sleeping product should good for my health \\
\cline { 2 - 3 } & FF4 & The sleeping product should look good \\
\cline { 2 - 3 } & FF5 & The sleeping product should have consistent quality \\
\cline { 2 - 3 } & FF6 & The sleeping product should have reasonable priced \\
\hline
\end{tabular}


Volume 3 Issue 9 (September 2021) PP. 265-276 DOI 10.35631/AIJBES.39018

\begin{tabular}{|c|c|c|}
\hline & FF7 & $\begin{array}{l}\text { The sleeping product should have suitable value } \\
\text { compared to the money }\end{array}$ \\
\hline \multirow{2}{*}{$\begin{array}{l}\text { Part III - Social- } \\
\text { Related Value }\end{array}$} & FS1 & $\begin{array}{l}\text { When buying sleeping products, I pay close attention to } \\
\text { the effect they have on my social life }\end{array}$ \\
\hline & FS2 & $\begin{array}{l}\text { The sleeping products I buy should help me make a good } \\
\text { impression on my environment }\end{array}$ \\
\hline \multirow{3}{*}{$\begin{array}{l}\text { Part IV - Personal- } \\
\text { Related Value }\end{array}$} & FP1 & $\begin{array}{l}\text { The sleeping product should be able to make me feel } \\
\text { good (happy) after I buy it }\end{array}$ \\
\hline & FP2 & The sleeping products must be comfortable when used \\
\hline & FP3 & The sleeping product should be able to be relaxing \\
\hline \multirow{5}{*}{$\begin{array}{l}\text { Part V - Sales } \\
\text { Promotion }\end{array}$} & SP1 & $\begin{array}{l}\text { I only purchase sleeping product if there is a price } \\
\text { discount on the product }\end{array}$ \\
\hline & SP2 & $\begin{array}{l}\text { I tend to buy more than usual when offered price } \\
\text { discounts }\end{array}$ \\
\hline & SP3 & $\begin{array}{l}\text { I would make more frequent purchases of sleeping } \\
\text { products if I had a coupon that offered a promotion }\end{array}$ \\
\hline & SP4 & $\begin{array}{l}\text { Free samples influences me to make unplanned purchase } \\
\text { of sleeping product }\end{array}$ \\
\hline & SP5 & $\begin{array}{l}\text { Buy one get one influences me to make unplanned } \\
\text { purchase of sleeping product }\end{array}$ \\
\hline \multirow{6}{*}{$\begin{array}{l}\text { Part VI - Social } \\
\text { Media Marketing }\end{array}$} & SM1 & $\begin{array}{l}\text { Social media is an effective platform for sleeping } \\
\text { products information search }\end{array}$ \\
\hline & SM2 & $\begin{array}{l}\text { Social media give an ease in information search of } \\
\text { sleeping products }\end{array}$ \\
\hline & SM3 & $\begin{array}{l}\text { Positive review of sleeping products from friends induce } \\
\text { buying }\end{array}$ \\
\hline & SM4 & $\begin{array}{l}\text { Positive reviews of sleeping products from strangers } \\
\text { induce buying }\end{array}$ \\
\hline & SM5 & $\begin{array}{l}\text { Social media influential than traditional media } \\
\text { (newspaper, magazine, etc) }\end{array}$ \\
\hline & SM6 & $\begin{array}{l}\text { Social media plays a role in making sleeping products } \\
\text { purchase decisions }\end{array}$ \\
\hline
\end{tabular}

This study intent to identify influence of customer perceived value (including product-related value, social-related value, and personal-related value), sales promotion, and social media marketing towards purchase decision on sleeping product. This research should collect minimum of 200 respondents of Generation Z lived in Jabodetabek or Bandung. The questionnaire consists of statements that rated from the scale of 1 (strongly disagree) to 5 (strongly agree) as the level of agreement. Then, the result of the questionnaire will be tested for validity and reliability. The validity test score must be above the r-table and the significant 
Volume 3 Issue 9 (September 2021) PP. 265-276

DOI 10.35631/AIJBES.39018

score below 0.05 . Also, the reliability test was done by calculating the Cronbach's alpha value have to greater than 0.6 that indicates the internal consistency of the scale is acceptable.

Journals and papers are used to support the research and as secondary sources. As such, questionnaires is the primary source of this research.

\section{Discussion and Analysis}

Based on the discussion, this study can conclude that there are five indicators that consumers consider before purchasing a sleeping product which are product value, social value, personal value, sales promotion and social media marketing. The result of this research can be used to determine marketing strategies and product strategies for sleeping products businesses. Furthermore, to determine the factors that affect purchase decisions of sleeping products on Generation Z, the following hypothesis is proposed

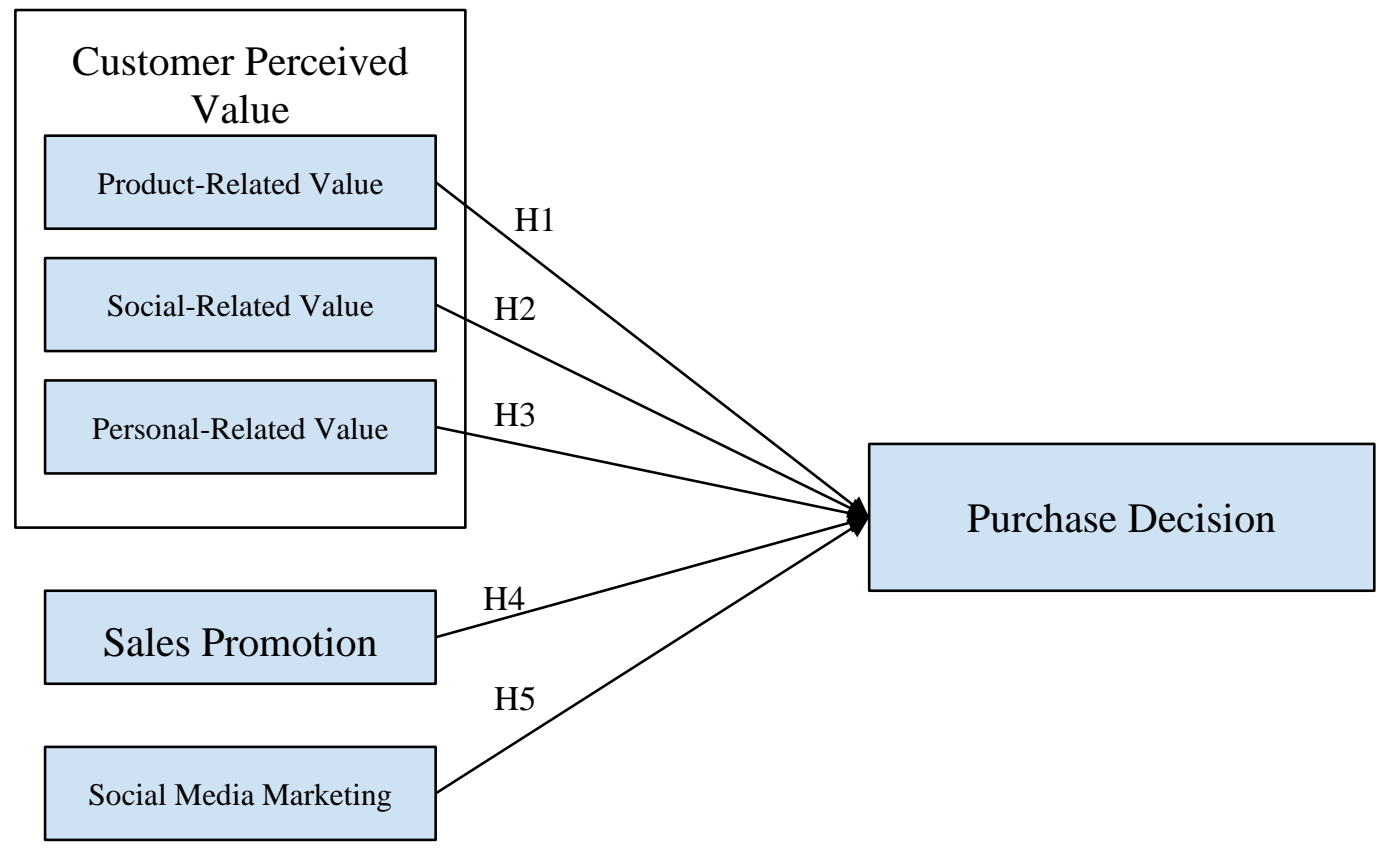

Source: Author's Interpretation

Figure 1. Conceptual Framework

The framework above is a combination of previous studies that have been stated before. The relationship between customer perceived value, sales promotion and social media marketing to purchase decision is obtained from several studies combined in one framework.

Furthermore, the questionnaire was filled by 220 respondents. The researcher will use a statistical approach, started with the validity and reliability test. The validity test result revealed that the value of Pearson Correlation is above 0.133 (r-table) and the significance value is 0.05 . Then, the reliability shows the Cronbach's alpha values are above 0.60 that indicates reliable. Then, the descriptive analysis that was done to find the most important or significant variable. The entire findings of the descriptive analysis are shown in table 2. 
Volume 3 Issue 9 (September 2021) PP. 265-276 DOI 10.35631/AIJBES.39018

Table 2: Descriptive Analysis

\begin{tabular}{|c|c|c|c|c|c|}
\hline \multicolumn{2}{|c|}{$\begin{array}{l}\text { Independent } \\
\text { Variables }\end{array}$} & Average & \multicolumn{2}{|c|}{ Independent Variables } & \multirow{2}{*}{$\begin{array}{c}\text { Average } \\
4.50 \\
\end{array}$} \\
\hline \multirow{5}{*}{$\begin{array}{l}\text { Purchase } \\
\text { Decision }\end{array}$} & PD1 & 4.42 & \multirow{3}{*}{$\begin{array}{c}\text { Personal- } \\
\text { Related } \\
\text { Value }\end{array}$} & PV1 & \\
\hline & PD2 & 4.28 & & PV2 & 4.76 \\
\hline & PD3 & 3.45 & & PV3 & 4.67 \\
\hline & PD4 & 4.20 & \multirow{5}{*}{$\begin{array}{c}\text { Sales } \\
\text { Promotion }\end{array}$} & SP1 & 3.30 \\
\hline & PD5 & 4.39 & & SP2 & 3.43 \\
\hline \multirow{7}{*}{$\begin{array}{c}\text { Product- } \\
\text { Related Value }\end{array}$} & FV1 & 4.53 & & SP3 & 3.54 \\
\hline & FV2 & 4.58 & & SP4 & 3.77 \\
\hline & FV3 & 4.68 & & SP5 & 3.86 \\
\hline & FV4 & 3.81 & \multirow{6}{*}{$\begin{array}{c}\text { Social } \\
\text { Media } \\
\text { Marketing }\end{array}$} & SM1 & 4.58 \\
\hline & FV5 & 4.64 & & SM2 & 4.58 \\
\hline & FV6 & 4.36 & & SM3 & 4.52 \\
\hline & FV7 & 4.57 & & SM4 & 4.17 \\
\hline \multirow{7}{*}{$\begin{array}{c}\text { Social- } \\
\text { Related Value }\end{array}$} & SV1 & 3.71 & & SM5 & 4.54 \\
\hline & SV2 & 3.66 & & SM6 & 4.42 \\
\hline & SM2 & 4.58 & & & \\
\hline & SM3 & 4.52 & & & \\
\hline & SM4 & 4.17 & & & \\
\hline & SM5 & 4.54 & & & \\
\hline & SM6 & 4.42 & & & \\
\hline
\end{tabular}

The scale 3 to 5 represents the scale of agreement. It shows that PV2 from personal value has the highest between all of the dimension which means should be in the highest consideration in a business. Then, the data were further processed by using the multiple linear regression (MLR) analysis. Based on the formula given from Lind, Douglas A., Marchal, William G., Wathen (2012), it can be interpreted that the equation of this study will be as follow: $\mathrm{Y}=1.537+0.229 \mathrm{X} 1+0.354 \mathrm{X} 2+0.247 \mathrm{X} 3+0.095 \mathrm{X} 4+0.160 \mathrm{X} 5$

The equation interprets that the purchase decision on sleeping product would have a value of 1.085 expect for constant when all independent variables have a zero value. An increase by 0 . 229 by one unit of product-related value, 0.354 by one unit of social-related value, 0.247 by one unit of personal-related value, 0.095 by one unit of sales promotion and 0.160 by one unit of social media marketing value.

Also, the researcher uses coefficient of determination as the percentage of variance in one variable that is predicted or explained by the other.

Table 3: Coefficient of Determination

\begin{tabular}{|c|c|c|c|c|}
\hline Model & $\mathbf{R}$ & R Square & $\begin{array}{c}\text { Adjusted R } \\
\text { Square }\end{array}$ & $\begin{array}{c}\text { Std. Error of the } \\
\text { Estimate }\end{array}$ \\
\hline
\end{tabular}


Volume 3 Issue 9 (September 2021) PP. 265-276

DOI 10.35631/AIJBES.39018

\begin{tabular}{|c|c|c|c|c|}
\hline 1 & .566 & .320 & .304 & 2.331 \\
\hline
\end{tabular}

Table 3 shows that R2 is 0.304 or $30.4 \%$. This demonstrates that all independent variables in this study influence purchase decisions toward sleeping products. The result indicates $30.4 \%$ change in purchase decision can be explained by product-related value, social-related value, personal-related value, sales promotion, and social media marketing. While the other $69.6 \%$ is caused by other factors outside the five independent variables in this study.

Then, researcher does $\mathrm{T}$ test to figure out the influence of each independent variables toward the variation of the dependent variable. The hypothesis is accepted if the significance value is less than 0.05 and $t$ value greater than 1.971 .

Table 4: T Test

\begin{tabular}{|c|c|c|l|}
\hline Hypothesis & $\begin{array}{c}\text { Sig } \\
\text { Value }\end{array}$ & $\begin{array}{c}\text { T } \\
\text { Value }\end{array}$ & Result \\
\hline $\begin{array}{c}\text { Product-Related Value have significant impact on consumer } \\
\text { purchase decision }\end{array}$ & 0.001 & 3.417 & Accepted \\
\hline $\begin{array}{c}\text { Social-Related Value have significant impact on consumer } \\
\text { purchase decision }\end{array}$ & 0.000 & 4.582 & Accepted \\
\hline $\begin{array}{c}\text { Personal-Related Value have significant impact on consumer } \\
\text { purchase decision }\end{array}$ & 0.042 & 2.046 & Accepted \\
\hline $\begin{array}{c}\text { Sales promotion have significant impact on consumer purchase } \\
\text { decision }\end{array}$ & 0.041 & 2.057 & Accepted \\
\hline $\begin{array}{c}\text { Social media marketing have significant impact on consumer } \\
\text { purchase decision }\end{array}$ & 0.007 & 2.738 & Accepted \\
\hline
\end{tabular}

Based on table 4, it can be seen that all independent values (product-related value, socialrelated value, personal-related value, sales promotion, and social media marketing) has significant positive impact on the purchase decision of sleeping products on generation $\mathrm{Z}$ in Jabodetabek and Bandung city.

\section{Conclusions}

Based on the researcher's findings, there are several conclusions to understand the customer preferences and factor influences purchase decision towards sleeping product among Generation $\mathrm{Z}$ in Jabodetabek and Bandung. Based on multiple linear regression analysis, product, social, and personal value, sales promotion, and social media marketing have a significant positive impact on purchase decisions, which can be seen from the p-value. It can be concluded that sleeping products should have several product functions, giving social value and fulfil personal value. Also, some of sales promotion can be implemented and using social media marketing to provide sleeping product's information. 
Volume 3 Issue 9 (September 2021) PP. 265-276

DOI 10.35631/AIJBES.39018

For the customer preferences, this study confirm customer needs and attitudes about sleep products. Sleeping products need prioritize the product performance for the quality. For the price of each sleeping product, customer are able to buy in price range between Rp 50.000-Rp 100.000. For the packaging and design, customers prefer packaging with a bottle and a brown theme (such as natural nature, shown in picture 3). Likewise for brands are divided into 2 , brand name and brand origin. Compared to the other product attributes (quality, price, packaging and design), brand name is the aspect that is least considered by customers as well as global brand is preferred by customers than local brand.

\section{References}

Aulia, S.A., Sukati, I., Sulaiman, Z., 2016. A Review: Customer Perceived Value and its Dimension. Asian J. Soc. Sci. Manag. Stud. 3, 150-162. https://doi.org/10.20448/journal.500/2016.3.2/500.2.150.162

Dawood Shamout, M., 2016. The Impact of Promotional Tools on Consumer Buying Behavior in Retail Market, International Journal of Business and Social Science.

Denizci Guillet, B., Kucukusta, D., 2016. Spa market segmentation according to customer preference. Int. J. Contemp. Hosp. Manag. 28, 418-434. https://doi.org/10.1108/IJCHM-07-2014-0374

Dubey, J., 2014. Personal Care Products: Sales Promotion and Brand Loyalty, (C) The Journal Contemporary Management Research.

Familmaleki, M., Aghighi, A., Hamidi, K., 2015. Analyzing the Impact of Promotion Mix on Consumer' S Purchase Decision. Adv. Soc. Humanit. Manag. 2, 72-81.

Hanaysha, J.R., 2018. An examination of the factors affecting consumer's purchase decision in the Malaysian retail market. PSU Res. Rev. 2, 7-23. https://doi.org/10.1108/prr-082017-0034

Jothi, L., 2015. A Study on Influence of Demographic Factors on Customers 'Preference towards Cosmetic Products. SUMEDHA J. Manag. 4, 39-48.

Khatib, F., 2016. The Impact of Social Media Characteristics on Purchase Decision Empirical Study of Saudi Customers in Aseer Region. Int. J. Bus. Soc. Sci. 7.

Kosticova, M., Husarova, D., Dankulincova, Z., 2018. Difficulties in Getting to Sleep and their Association with Emotional and Behavioural Problems in Adolescents: Does the Sleeping Duration Influence this Association? Int. J. Environ. Res. Public Heal. Artic. https://doi.org/10.3390/ijerph17051691

Leger, D., Beck, F., Richard, J.-B., Godeau, E., 2012. Total Sleep Time Severely Drops during Adolescence. PLoS One 7, 45204. https://doi.org/10.1371/journal.pone.0045204

Lemmer, B., 2007. The sleep-wake cycle and sleeping pills. Physiol. Behav. 90, 285-293. https://doi.org/10.1016/j.physbeh.2006.09.006

Nguyen, T.N., Vu, P.A., Phan, T.T.H., Cao, T.K., 2015. An Exploratory Investigation into Customer Perceived Value of Food Products in Vietnam. Int. Bus. Res. 8, 1. https://doi.org/10.5539/ibr.v8n12p1

Prasad, Shantanu, Garg, A., Prasad, Saroj, 2019. Purchase decision of generation Y in an online environment. Mark. Intell. Plan. 37, 372-385. https://doi.org/10.1108/MIP-02-20180070 
Volume 3 Issue 9 (September 2021) PP. 265-276 DOI 10.35631/AIJBES.39018

Tu, K.M., Spencer, C.W., El-Sheikh, M., Erath, S.A., 2019. Peer Victimization Predicts Sleep Problems in Early Adolescence. J. Early Adolesc. 39, 67-80. https://doi.org/10.1177/0272431617725199

Venkatraman, V., Clithero, J.A., Fitzsimons, G.J., Huettel, S.A., 2012. New scanner data for brand marketers: How neuroscience can help better understand differences in brand $\begin{array}{llll}\text { preferences. } & \text { J. Consum. } & \text { Psychol. }\end{array}$ https://doi.org/10.1016/j.jcps.2011.11.008

Winsler, A., Deutsch, A., Vorona, R.D., Payne, P.A., Szklo-Coxe, M., 2015. Sleepless in Fairfax: The Difference One More Hour of Sleep Can Make for Teen Hopelessness, Suicidal Ideation, and Substance Use. J. Youth Adolesc. 44, 362-378. https://doi.org/10.1007/s10964-014-0170-3

Xuegeng, C., 2012. 陈学庚 1, 钟陆明 2 （1.4, 8-15.

Yashodha, G., n.d. A STUDY ON CONSUMER PREFERENCES TOWARDS THE SALES PROMOTION TECHNIQUES ADOPTED BY THE FAST MOVING CONSUMER GOODS (FMCG) COMPANIES.

Yogesh, F., Yesha, M., 2014. Effect of Social Media on Purchase Decision. Pacific Bus. Rev. Int. $6,45-51$. 